\title{
DELEGATION AND DUE PROCESS
}

\author{
DONALD A. DRIPPS*
}

The nondelegation doctrine, first used to strike down a federal statute in 1935, constitutionally prohibits excessive delegation of congressional power. ${ }^{1}$ Delegation becomes excessive when Congress transfers legislative powers without providing adequate guidance about how those powers are to be exercised. Although the Supreme Court used the doctrine once the following year, ${ }^{2}$ nearly five decades then passed before the Court again held legislation unconstitutional on a similar basis. During those fifty years, Congress delegated far-reaching powers to a host of executive officers and independent agencies, often with minimal direction on the use of the powers. The courts, however, always found sufficient guidance in the delegation and thus no conflict with the Constitution. ${ }^{3}$

* Associate Professor, University of Illinois College of Law. B.A., Northwestern University, 1980; J.D., University of Michigan, 1983. I appreciate the valuable comments of colleagues Gerry Bradley, Ron Rotunda, and Steve Ross, who do not share niy views.

1. See Panama Ref. Co. v. Ryan, 293 U.S. 388, 433 (1935) (invalidating section 9(c) of the National Industrial Recovery Act (NIRA)); A.L.A. Schechter Poultry Corp. v. United States, 295 U.S. 495, 551 (1935) (invalidating NIRA in its entirety).

2. In Carter v. Carter Coal Co., 298 U.S. 238, 309-11 (1936), the Court struck down the Bituminous Coal Conservation Act of 1935 primarily for lack of federal jurisdiction under the commerce clause, but also because the Act delegated regulatory power to certain private groups.

3. To be legitimate, delegations must be guided by intelligible principles. See, e.g., Arizona v. California, 373 U.S. 546, 584-94 (1963) (Secretary of Interior's power to apportion Colorado River waters held limited and guided by, imter alia, congressional limitations on amount of water that could be allocated to California); Falıey v. Mallonee, 332 U.S. 245, $249-53$ (1947) (holding Federal Home Loan Bank Board's discretion to make regulations is guided by "well-known and generally accepted standards" drawn from the long history of banking regulation and corporate management); American Power \& Light Co. v. SEC, 329 U.S. 90, 104-05 (1946) (holding SEC's implementation of Public Utility Holding Company Act is guided by standards in the Act, which, though facially vague, "cannot be said to be without mcaning, especially to those familiar with corporate realities," and by purposes of the Act, by the Act's factual background, and by statutory context of the Act); Yakus v. United States, 321 U.S. 414, 423-27 (1944) (administrator of Emergency Price Control Act, in setting prices for commodities, must nieet statutory guidelines of fairness and equity and due consideration to prevailing prices; "the boundaries of the field of the administrator's permissible action are marked by the statute"); Hampton v. United States, 276 U.S. 394, 406-11 (1928) (Tariff Comnission, in fixing rates, held guided "by an intelligible principle to which the person or body authorized to fix such rates is directed to conform," i.e., that the tariff should equal the difference between the prices of foreign and domestic production of the good); Amalgamated Meat Cutters v. Connally, 337 F. Supp. 737, 746-47 (D.D.C. 1971) (holding Cost of Living Council is guided by statutory floor on prices (not less than those prevailing when Economic Stabilization Act was passed), by prohibition on singling out a particular industry or sector of the economy, and by purpose of the Act (to stabilize prices), its factual background, and statutory context); Synar v. United States, 626 F. Supp. 1374, 1387-89 (D.D.C.) (Gramm-Rudman-Hollings Act contains required gui- 
But at about the midpoint of this period, judicial dissatisfaction with the exercise of delegated powers began to inspire decisions based on the fifth amendment's due process clause. ${ }^{4}$ Imitially somewhat amorphous, these decisions have developed into a formulaic doctrine of procedural due process. 5 Under current law, an individual aggrieved by government action must establish that the government has deprived him of a protected interest without. providing appropriate procedures. ${ }^{6}$ The Court has held that protected interests imclude government welfare benefits ${ }^{7}$

dance by establishing a "maximum deficit amount," by requiring Office of Management and Budget (OMB) and Congressional Budget Office (CBO) to estimate and project current and future years' economic growth, revenues, and outlays, by setting forth specific assumptions to be used by OMB and $\mathrm{CBO}$, by defining terms, and by referring to years of administrative and congressional experience in making similar economic projections), aff'd sub nom. Bowsher v. Synar, 478 U.S. 714 (1986).

4. Cafeteria \& Restaurant Workers Umion v. McElroy, 367 U.S. 886, 894-99 (1961); see also Kent v. Dulles, 357 U.S. 116, 129-30 (1958) (narrowly construing statute delegating power to regulate foreign travel in order to avoid potential conflict with substantive due process right to travel). These cases exemplify a broader judicial trend toward close scrutiny of government security programs that denied government benefits to those with suspected leftist political opimions. See Rubin, Due Process and the Administrative State, 72 CALIF. L. REv. 1044, 1053-60 (1984).

5. The classic article recounting (and recasting) the doctrine is Friendly, Some Kind of Hearing, 123 U. PA. L. REv. 1267 (1975). For another good, and more current, general treatment, see Rubin, supra note 4, at 1047-82.

6. See Davidson v. Cannon, 474 U.S. 344 (1986); Daniels v. Williams, 474 U.S. 327 (1986); Cleveland Bd. of Educ. v. Loudermill, 470 U.S. 532 (1985); Mathews v. Eldridge, 424 U.S. 319 (1976); Perry v. Sinderman, 408 U.S. 593 (1972); Board of Regents v. Roth, 408 U.S. 564 (1972); Goldberg v. Kelly, 397 U.S. 254 (1970). Current doctrine requires one claiming a due process violation to establish, first, that government action has deprived her of a protected interest, i.e, "life, liberty, or property." Individual liberty interests may be groimded in the Constitution, including the due process clause itself. See Ingraham v. Wright, 430 U.S. 651, $672-74$ (1977) (fourteenth amendment). Liberty interests inay also arise from statutes that, subject only to revocation for specified causes, entitle the individual to freedoin froin otherwise legal restraints. See, e.g., Greenholtz v. Inmates of the Neb. Penal \& Correctional Coinplex, 442 U.S. 1, 11-16 (1979) (ininates accorded due process even though parole determinations need not include either formal hearings or statements of evidence relied upon). Property interests in governinent benefits depend on statutory entitleinents. Courts will not deem a statutory entitleinent to be a property interest unless the reeipient enjoys more than a subjective unilateral expectation that the benefit is terminable only for cause. See, e.g., Loudermill, 470 U.S. at 538-39 (Ohio statute requiring for-cause-only termination for civil servants creates property interest); Memphis Light, Gas \& Water Div. v. Craft, 436 U.S. 1, 9-12 (1978) (finding entitlement to public utility services). Whether the Constitution specifies an irreducible minimuin of property interests, as it does with liberty interests, is an open question. For iny own views, see infra notes $94-96$ and aecompanying text.

If a plaintiff establishes a protected interest, the court then asks whether the deprivation was aceompanied by "the process that was due." In answering this second question, courts apply the three-factor analysis set out in Mathews, 424 U.S. at 334-35. That analysis accounts for the goverument's interest in avoiding procedural coinplexity, the individual's interest in avoiding erroneous deprivation, and the potential contribution that additional proeedures inight make to the accuracy of results.

Recently the Court has held that deprivation of a protected interest involves more than causing the loss of an individual's entitlement. See Davidson, 478 U.S. at 347; Daniels, 478 U.S. at 330-31.

7. Goldberg, 397 U.S. at 261-62. 
and tenured public employment, ${ }^{8}$ and that they also arise from state-law entitlements to private wealth. ${ }^{9}$ Thus, almost the entire spectrum of administrative activity is now subject to judicial scrutimy under the due process clause. Along the way, the Court, under authority of the fourteenth amendment, has applied the same doctrine to the states. ${ }^{10}$ Once a court finds a protected interest, the procedures required for its protection depend on whether the individual's stake in a correct decision exceeds the government's interest in procedural simplicity. ${ }^{11}$

This line of cases, now voluminous even at the Supreme Court level, ${ }^{12}$ assumes the Court's authority to require that the legislature follow judicially devised procedures to allocate entitlements that it need not provide at all. Based on a largely conclusory justification, the Court holds that the legislature may not define entitlements in solely procedural terms. ${ }^{13}$ Although the Court has held to this line, I hope to point out that the rationale for that holding has proven unsatisfactory.

My thesis is that the connection between the nondelegation principle and the procedural due process cases is more than historical. I suggest that the due process cases are an enforcement tool for the nondelegation doctrine. Individuals have a right-a "liberty interest," if you will-to protection agamst the exercise of legislative power except as the Constitution provides. If that is so, then Congress's power to abohish disputed entitlements is no argument against judicially imposed procedures to ensure the allocation of entitlements according to congressional standards. In short, I submit that the nondelegation doctrine forbids the legislative defimition of entitlements in purely procedural terms.

Acceptance of this thesis would significantly alter the due process analysis. First, since every exercise of delegated legislative power that threatens an individual with injury presents a question of compliance with legislative directions, any mdividual so threatened would, under this analysis, enjoy a protected hiberty interest. This approach would end the largely arbitrary demial of review to those facmg deprivations that do not

8. Loudermill, 470 U.S. at 538-39; Perry, 408 U.S. at 597-98; Roth, 408 U.S. at 567-78.

9. E.g., Londoner v. City \& County of Denver, 210 U.S. 373 (1908). 260-71.

10. See, e.g., Loudermill, 470 U.S. at 538-48; Roth, 408 U.S. at 538-48; Goldberg, 397 U.S. at

11. See Mathews, 424 U.S. at 335.

12. A partial list would include Loudermill, 470 U.S. at 532; Logan v. Zimmerman Brush Co., 455 U.S. 422 (1982); Barry v. Barchi, 443 U.S. 55 (1979); Vitek v. Jones, 445 U.S. 480 (1980); Bishop v. Wood, 426 U.S. 341 (1976); Meachum v. Fano, 427 U.S. 215 (1976); Mathews, 424 U.S. at 319; Paul v. Davis, 424 U.S. 693 (1976); Goss v. Lopez, 419 U.S. 565 (1975); Arnett v. Kennedy, 416 U.S. 134 (1974); Roth, 408 U.S. at 564; Perry, 408 U.S. at 593; Bell v. Burson, 402 U.S. 535 (1971); Wisconsin v. Constantineau, 400 U.S. 433 (1971); Goldberg, 397 U.S. at 254.

13. E.g., Loudermill, 470 U.S. at 541. 
fit into judicial categories of liberty or property. ${ }^{14}$ Second, the focus of the balancing formula for determining the process due would shift from the substantive weight of the interests involved to the nature of the standards governing the power exercised. Finally, if the due process cases really rest on the nondelegation doctrine, constitutional scrutiny of state entitlement decisions would be substantially curtailed, because the Constitution does not recognize any enforceable right to the structure of state. governments.

Part I sets out the foundations of the nondelegation doctrine. Part II considers how the nondelegation doctrine explains the due process cases better than the prevailing theory. Part III explores and defends the implications of a delegation approach to procedural due process cases.

\section{Two Versions of the Nondelegation Doctrine}

\section{A. The Structural Integrity Principle.}

Article I of the Constitution vests "all legislative powers herein granted" in Congress. The Supreme Court has always read this provision to limit the delegation of legislative powers to noncongressional actors. ${ }^{15}$ Nevertheless, practical government involves substantial delegation of authority, and until 1935 the Court, although consistently maintaining in dicta the existence of a nondelegation doctrime, had never held a delegation of legislative power unconstitutional. ${ }^{16}$ If there is, as some have questioned, ${ }^{17}$ a nondelegation doctrine, what values does it serve?

At one level, the justification for the doctrine is clear enough. According to the "structural integrity principle" the Constitution establishes a form of government based on separation of powers and popular representation, and delegation without limit circumvents this constitutional structure. ${ }^{18}$ For example, if Congress simply delegated all its pow-

14. See Goldberg, 397 U.S. at 264-66.

15. See J.W. Hampton, Jr. \& Co. v. United States, 276 U.S. 394 (1928); Field v. Clark, 143 U.S. 649, 692 (1892) ("That Congress cannot delegate legislative power to the President is a principle universally recognized as vital to the integrity and maintenance of the system of government ordained by the Constitution."); Wayman v. Southard, 23 U.S. (10 Wheat.) 1, 36 (1825).

16. See, e.g., Schwartz, Of Administrators and Philosopher-Kings: The Republic, the Laws, and the Delegations of Power, 72 Nw. U.L. REv. 443, 454 (1978) ("Panama Refining Co. v. Ryan was the first case in which a delegation of legislative power was ruled invalid by the Supreme Court.").

17. See, e.g., Federal Power Comm'n v. New England Power Co., 415 U.S. 345, 352-54 (1974) (Marshall, J., concurring) (Supreme Court has "virtually abandoned" nondelegation doctrine); $1 \mathrm{~K}$. Davis, ADMinistrative Law Treatise 151-52 (2d ed. 1978) (same); Duff \& Whiteside, Delegata Potestas Non Potest Delegari: A Maxim of American Constitutional Law, 14 CoRnell L.Q. 168, 196 (1929) (nondelegation doctrine is based on "thinnest of implications" from constitutional text).

18. See S. Barber, The Constitution and the Delegation of Congressional Power 37 (1975) ("The best theoretical foundation for the rule of nondelegation is the simple expectation in 
ers to the President-as the German Reichstag did to Hitler in 193319 the protection afforded to individual liberty by this separation of powers would be lost.

A.L.A. Schecter Poultry Corp. v. United States, handed down in 1935, reflects the Court's justifiable concern with the integrity of the government. There, the Court struck down the National Industrial Recovery Act, which delegated to the President nearly all of the legislative commerce power-in effect, the power to plan the national economy. ${ }^{20}$ Although the Act contemplated presidential approval of "Codes of Fair Competition" promulgated in the first instance by business and labor groups, the Act allowed the President to make any change that a proposed code required for the "protection of ... the public interest," and it also authorized the President to promulgate and enforce codes on his own motion. ${ }^{21}$

the constituent act of establishing government that neither the government nor any of its parts should change the constitutional arrangement of offices and powers."). Professor Barber distinguishes this concern for constitutional supremacy from the separation of powers because "a principle of nondelegation is a presupposition of the separation of powers, not a rule derived from the separation of powers." Id. His analysis is in part persuasive; even if a constitution ordained a government consisting solely of a supreme parliament, the parliament could not constitutionally delegate all its powers to some private person. On the other hand, citizens in a society without a written constitution very well might jealously guard the separation of powers. In such a society, separation of powers would itself furnish a reason for a nondelegation doctrine. Thus, under a constitution such as that of the United States, which affirms both constitutional supremacy and separation of powers, the nondelegation doctrine serves two independent but mutually reinforcing values. Together, constitutional supremacy and separation of powers imply both the strnctural integrity principle and the intelligible principle requirement.

19. See Office of United States Chief of Counsel for Prosecution of Axis CrimlNALITY, NAZI CONSPIRACY AND AggRESSION 8-11 (1947).

20. See Aranson, Gellhorn \& Robinson, $A$ Theory of Legislative Delegation, 68 CoRNELL L. REV. 1, 8 (1982) (NIRA gave President "almost total control of the economy").

21. The Act, which is reprinted in A.L.A. Schecter Poultry Corp. v. United States, 295 U.S. 495, $521 \mathrm{n} .4$ (1935), authorized groups of businessmen to submit for presidential approval "Codes of Fair Competition" fixing prices, output, and wages. Under NIRA section 3(a), any code so promulgated could be modified by the President "in furtherance of the public interest" with such exceptions as "the President in his discretion deems necessary to effectuate the policy [t]herein declared." Under section 3(d), if producers could not agree upon a code, the President was authorized to promulgate one, either at the request of an interested person or at his own imstance. The extraordinary vice of the NIRA was not its delegation of preliminary power to private persons, but its delegation of the power to plan the national economy to the President. The briefs in the Schecter Poultry case concentrate on presidential power and virtually ignore the role of the private producer associations:

By the Recovery Act Congress has delegated to the president of the United States the power to approve so-called codes of fair competition which may be presented to him by "representative" trade or industrial associations. When and if such codes of fair competition are approved by the President each and every provision thereof has the full force and effect of law and violations thereof are constituted crimes. It is our contention that such a delegation of power is purely and simply a delegation of legislative power to the President of the United States on account of the fact that Congress has set up no intelligible policies 
The aggrandizement of presidential power effected by the Act presented an obvious danger to the integrity of the government. Whatever one may think of any given President, no President ought to have the power to exclude inclividuals from commerce arbitrarily or vindictively. Imagine a Congressman considering whether to oppose the President on an inportant matter. Under the Act, could such a Congressman exclude the possibility that his constituents might find the prices of their produce raised to ruinous heights, or lowered to rumous depths? That their quota of national output miglit be suddenly reduced? When the delegated power is so sweeping and the delegate already so powerful, the theoretical revocability of the delegation is irrelevant. The legislative check on executive action conld be subverted by the exercise of the very power granted by the disputed delegation.

\section{B. The Intelligible Principle Requirement.}

The Court has also struck down far less sweepmg delegations, under circumstances that one may not fairly describe as involving the integrity of the government. These cases-Panama Refining Co. v. Ryan, ${ }^{22}$ INS v. Chadha, ${ }^{23}$ and Bowsher v. Synar ${ }^{24}$-reflect on a sinall scale the values that were more dramatically at stake in Schecter Poultry. Departure from the constitutional structure is forbidden because the Constitution specifies rules of validity for legislation, rules that serve fundamental political values. ${ }^{25}$ Circumvention of the constitutional process of lawmaking, even on issues of only modest political interest, can offend those values and thus offend the requireinent that delegations and delegates remain subject to the pluralist constraints imposed on Congress by the Constitution. Protection of these values is embodied in the so-called "intelligible principle" requirement, which inandates that Congress guide all delegations by an intelligible principle.

Article I not only vests legislative power in a popular assembly; it also places difficult obstacles in the path of any exercise of the powers

to govern the President, no standards to guide and restrict the President in his action, and no procedure for making determinations in conformity with due process of law.

Brief for A.L.A. Schecter Poultry Corp. at 25-26, Schecter Poultry, 295 U.S. at 495 (Nos. 854 \& 864). Justice Brandeis, a supporter of the administration, reportedly told an administration representative not that the Schecter decision condemned diffusing power among private groups, but rather that it demonstrated the Court's unwillinguess to "let this government centralize everything." Aranson, Gellhorn \& Robinson, supra note 20, at 10 n.35 (quoting A. SCHLEsINGER, THE Politics of UPheAVAL 280 (1960)).

22. 293 U.S. 388 (1935).

23. 462 U.S. 919 (1983).

24. 478 U.S. 714 (1986).

25. See Panama Ref. Co. v. Ryan, 293 U.S. 388, 421 (1935) (Congress may not abdicate "the essential legislative functions with which it is [constitutionally] . . . vested."). 
granted to Congress. The bicameral structure of Congress and the President's veto power subject legislative decisions both to subsequent electoral accountability and to the present scrutimy of diverse interests. The Constitution thus establishes a form of pohtical pluralism: no legislation may succeed that offends either the states as semisovereign bodies, any coalition based on popular sentiment or local interest, or the President's national constituency. ${ }^{26}$ The Constitution states that no legislation shall become law without satisfying these checks. Reflecting a substantive preference for either private ordering or state regulation over federal legislation, article I places the burden of creating federal positive law on the proponents of congressional action. ${ }^{27}$

26. See U.S. CoNST. art. I, $\S 7$, cl. 2 . In defending the bicameralism and presentment procedures, the Framers emphasized both the danger of usurpation, which supports the structural integrity principle, and the usefulness of pluralism in preventing unwise laws, which supports the intelligible principle requirement. See THE FEDERALIST No. 62, at 317-18 (A. Hamilton or J. Madison) (M. Beloff ed. 1987):

First. . . [A] senate, as a second branch of the legislative assembly, distinct from, and dividing the power with, a first, must be in all cases a salutary check on the government. It doubles the security to the people by requiring the concurrence of two distinct bodies in schemes of usurpation or perfidy, where the ambition or corruption of one would otherwise be sufficient ....

Second. The necessity of a senate is not less indicated by the propensity of all single and numerous assemblies, to yield to the impulse of sudden and violent passions, and to be seduced by factious leaders, into intemperate and pernicious resolutions .... . [A] body which is to correct this infirmity ought itself be frec from it, and consequently ought to be less numerous. It ought, inoreover to possess great firmness, and consequently ought to hold its authority by a tenure of considerable duration.

Hamilton made the same points in THE FEDERALIST No. 73, at 376-77 (M. Beloff ed. 1987), while defending the presidential veto:

The primary inducement to conferring the power in question upon the executive, is to enable him to defend himself; the secondary, is to increase the chances in favour of the community against the passing of bad laws, through haste, madvertence, or design. The oftener a measure is brought under examination, the greater the diversity in the situations of those who are to examme it, the less must be the danger of those errors which fiow from want of due deliberation, or those missteps which proceed from the contagion of some common passion or interest. It is far less probable that culpable views of any kind should imfect all the parts of the government at the same moment and in relation to the same object, than that they should by turns govern and mislead every one of them.

It may perhaps be said, that the power of preventing bad laws includes that of preventing good ones; and may be used to the one purpose as well as to the other. But this objection will have little weight with those who can properly estimate the inischiefs of that inconstancy and mutability in the laws, which form the greatest blemish in the character and genius of our governunents. They will consider every institution calculated to restrain the excess of law-making, and to keep things in the same state in which they may happen to be at any given period, as much more hikely to do good than harm; because it is favorable to greater stability in the system of legislation. The injury which may possibly be done by defeating a few good laws will be amply compensated by the advantage of preventing a number of bad ones.

27. See J. Ely, DEMOCRACY AND DISTRust 133-34 (1980) ("Much as liberals may not like it, one reason we have broadly based representative assemblies is to await something approaching a consensus before government intervenes.") (footnote omitted); Mayton, The Possibilities of Collective Choice: Arrow's Theorem, Article I, and the Delegation of Legislative Power to Administrative Agencies, 1986 DUKe L.J. 948, 957-58; Wright, Beyond Discretionary Justice, 81 YALE L.J. 575, 584-85 (1972). 
The Court recently has taken three opportunities to affirm unequivocally the importance of procedural checks on legislative action $\mathrm{m}$ cases not involving any politically dangerous transfer of power. In INS $v$. Chadha, the Court struck down the one-house legislative veto as an unconstitutional circumvention of the presentment and bicameralism requirements. ${ }^{28}$ The Court reasoned that by delegating legislative power to some of its members, Congress could take legislative action without satisfying the political constramts of article $I$. The initial passage of the delegating legislation could not satisfy the constitutional rules of validity, because the delegating legislation included no criteria-no intelligible principle-restricting the delegate's subsequent policy choice. ${ }^{29}$

Justice Stevens, joined by Justice Marshall, took a similar view while concurring in Bowsher v. Synar. ${ }^{30}$ The Gramm-Rudman-Hollings Act assigned the Comptroller General authority to determine the specific budget cuts required by Congress's failure to meet deficit reduction targets. The Bowsher majority viewed this determination as an inherently executive power, and the Comptroller as an agent of Congress. Since Congress may not, any more than a real estate swindler, convey what it does not rightfully own, the statute's delegation usurped presidential powers in violation of article $\mathrm{II.} .^{31}$

In Justice Stevens's view, lowever, the statute, like the legislative veto at issue in Chadha, conferred legislative power on a congressional agent. ${ }^{32}$ This seems a more accurate description of the power at issue. The appropriations power is a core legislative prerogative, and the ultimate effect of the Comptroller General's decision would have been to alter appropriations. The Act itself provided that if the automatic cuts were lield unconstitutional, the power to cut would revert to Congress. ${ }^{33}$ Even if the Act lad assigned the disputed functions to an executive agent, such as the Director of the Office of Management and Budget, Congress could have passed subsequent appropriations reinstating the items cut by the Executive. Justice Stevens maintained that since the statutory criteria for making the cuts were not self-executing, the statute effectively delegated legislative appropriations power, a power that could

28. 462 U.S. 919 (1983); see also supra note 26 (discussing presentment and bicameralism requirements).

29. Chadha, 462 U.S. at 954-55. Section 244(c)(2) of the Immigration and Nationality Act provided only that deportation would proceed if either House passed a resolution "stating in substance that it does not favor the suspension of such deportation." See id. at 925.

30. 478 U.S. 714, 736 (1986) (Stevens, J., concurring).

31. Id. at 726.

32. Id. at 751-52.

33. Id. at $750-51$. 
not be delegated without violating article I..$^{34}$

Botl Chadha and the Bowsher concurrence may be read as implicatimg the structural integrity principle, since in both cases Congress delegated legislative power to its own creatures. As Justice Stevens argued, such delegation presents a risk of congressional self-aggrandizement absent from delegations to the President or independent agencies. ${ }^{35}$ If the initial delegation, even to congressional creatures, were specific enough, there would be no reason to prohibit it. That is, if both Houses and the President knew the policy import of a delegation to one House, or to a congressional agent, the delegating legislation's bicameral passage and successful presentment would satisfy article I.

Justice Stevens's concern with congressional circumvention of article $\mathrm{I}$ is, I think, more urgent in Chadha, because there the veto could reverse the exercise of delegated power for any reason or no reason; the delegation of the veto power to the two Houses contained no intelligible principle. ${ }^{36}$ On the other hand, in cases involving an intelligible principle clear enough for the delegate to apply and the courts to police, Congress lias no reason for delegating the power to agents within its control. Put another way, the legislative veto is unconstitutional because it is useful only to the extent that it circumvents article I.

The Court's recent decision in Morrison v. Olson, ${ }^{37}$ upholding the constitutionality of the special prosecutor provisions of the Ethics of Government Act, implies no dechine in judicial skepticism about assignment of legislative powers to congressional agents. The Morrison Court decided only that Congress may, under certain circunistances, assign executive power to an office imsulated to a degree from presidential removal. This decision may seem at odds with the Bowsher najority opinion, ${ }^{38}$ but it in no way casts doubt on Chadha. Moreover, to the extent that Morrison undermines the majority position in Bowsher without overruling the decision, Morrison may even bolster the precedential force of Justice Stevens's concurrence.

34. Id. at $757-58$.

35. Id.

36. See Chadha, 462 U.S. at 925; supra note 29. In contrast, while the Comptroller General's task at issue in Bowsher was far from ministerial, the Gramm-Rudman-Hollings Act surely provided an intelligible principle for its exercise.

37. 108 S. Ct. 2597 (1988).

38. Bowsher and Morrison can be reconciled by classifying the special counsel as a sort of independent agency. Since Congress plays no role in the removal of a special counsel, footnote four of the Bowsher opinion recognizes the constitutionality of limits on the President's removal power. See 478 U.S. at 725 n.4. But it is hard to understand why the transfer of executive power to Congress is less legitimate than the transfer of executive power to an officer not recognized at all in the constitutional text. The tendency of the Bowsher majority's analysis to undermine the constitutionality of independent agencies is another point in favor of Justice Stevens's concurrence. 
At the extreme, legislative limits on executive powers may threaten the structural integrity principle. But delegation of executive power is not subject to the intelligible principle requirement; personal direction by, and accountability to, the President are the constitutionally provided mechanisms for effective administration. Simce the President's inherent constitutional power is insufficient, without legislative authorization, to abridge most individual freedoms, the constitutional checks on legislation are likewise checks on executive action. ${ }^{39}$ With respect either to enforcing legislation or to exercismg inherent constitutional powers, the President is not subject to any checks parallel to the bicameralism and presentment requirements that confront the exercise of legislative power. ${ }^{40}$ Thus, even if one reads Morrison to permit legislative usurpa-

39. See Youngstown Sheet \& Tube Co. v. Sawyer, 343 U.S. 579 (1952) (inherent presidential power does not authorize seizure of private property to further an undeclared war).

40. See The Federalist No. 70, at 361 (A. Hamilton) (M. Beloff ed. 1987):

Upon the principles of a free government, inconveniences from the source just mentioned inust necessarily be submitted to in the formation of the legislature; but it is unnecessary, and therefore unwise, to introduce them into the constitution of the executive. It is here, too, that they nuay be most pernicious. In the legislature, pronuptitude of decision is oftener an evil than a benefit. The differences of opinion, and the jarrings of parties in that department of the governnient, though they may sonietimes obstruct salutary plans, yet often promote deliberation and circumspection; and serve to cheek excesses in the majority. When a resolution, too, is once taken, the opposition inust be at an end. That resolution is a law, and resistance to it punishable. But no favorable circunistances palliate, or atone for the disadvantages of dissention in the executive departnient. Here they are pure and unmixed. There is no point at which they cease to operate. They serve to entbarrass and weaken the executive of the plan or measure to which they relate, from the first step to the final conclusion of it. They constantly counteract those qualities in the exeeutive, which are the inost necessary ingredients in its conpostion-vigour and expedition. And this without any counterbalancing good.

Thus, when the issue is the constitutionality of legislative restrictions on inherent executive powers, the only questions to ask are whether the powers so linited are indeed inherently executive and whether the congressional limitation threatens congressional self-aggrandizement in violation of the structural integrity principle. In Morrison, $108 \mathrm{~S}$. Ct. at 2619, the Court assumed that law enforcement is an inherently executive power-an assunntion that has been subjected to acute criticism. See Bradley, Law Enforcement and Separation of Powers, 30 ARIz. L. REV. - (forthcoiring, 1988). The Court then concluded that the Ethics in Government Act did not threaten presidential power to the benefit of Congress. See $108 \mathrm{~S}$. Ct. at 2616-22. This conclusion nray refiect the idea that some portion of the Executive's prosecutorial power is insulated front executive control. But it is more plausible to read the Court's opinion as holding that the Ethics in Governnent Act's "for cause" provision governing removal of a special counsel by the Attorney General falls short of insulating the special counsel from exeeutive control. Cf. Miller, Independent Agencies, 1986 SUP. CT. Rev. 41, 87.

Because the President's order to an officer to take an action within the scope of the officer's discretion is a legally valid action, the officer's refusal to follow the order can easily be considered to be a form of "neglect of duty" or "malfeasance" for which renoval is expressly provided under the terms of the statutes establishing purportedly "independent" agencies.

Id. (footnote omitted). But even on the assumption that Morrison allows Congress to create an officer exercising executive powers who is rentovable "only in accordance with the will of Congress as expressed in the Act," $108 \mathrm{~S}$. Ct. at $2620 \mathrm{n.33}$, the constitutionality of legislative limits on executive power has little to do with constitutional limits on legislative power. 
tion of executive powers, ${ }^{41}$ the decision casts no doubt on the Court's seriousness about the constitutional checks on the exercise of legislative power.

Contemporary decisions thus reflect the Court's concern with subjectimg the exercise of legislative power to article I requirements. Substantive pohtical values, rather than mere formalism, support this concern. By deiegating legislative power without concomitant legislative guidelines, Congress enables the creation of law without the affirmative approval of the constituencies represented by the actors in the article I process.

Modern defenders of the nondelegation doctrime tend to obscure this point by emphasizing the need for legislative accountability. Concurring in Industrial Union Department v. American Petroleum Institute, ${ }^{42}$ thenJustice Rehnquist defended the doctrine as follows:

As formulated and enforced by this Court, the nondelegation doctrine serves three important functions. First, and most abstractly, it ensures to the extent consistent with orderly governmental administration that important choices of social policy are made by Congress, the branch of our Government most responsive to the popular will. Second, the doctrine guarantees that, to the extent Congress finds it necessary to delegate authority, it provides the recipient of that authority with an "intelhgible principle" to guide the exercise of the delegated discretion. Third, and derivative of the second, the doctrine ensures that courts charged with reviewing the exercise of delegated legislative discretion will be able to test that exercise against ascertainable standards. ${ }^{43}$

The need to review agency actions against legislative standards, as the Chief Justice concedes, depends on the unconstitutionality of a standardless delegation in the first imstance. So too does the second reason; if the Constitution does not forbid standardless delegations, there is no constitutional need for congressional direction. The case for the imtelligible principle requirement then condenses to the argument that Congress itself must make certain kinds of policy decisions, an argument that the Chief Justice predicates on accountability. ${ }^{44}$

Many distinguished commentators liave defended this emphasis on

41. It is worth pointing out that the perceived defect of prosecutorial independence is not an objectionably lax refusal to prosecute, but an objectionably overzealous insistence on prosecution. See 108 S. Ct. at 2638-41 (Scalia, J., dissenting). The Ethics in Governinent Act, however, made no attempt to limit, and could not constitutionally have limited, the President's pardon power under article II, section 2 , clause 2 . That power can nullify any prosecution, even before the investigation begins. See Ex Parte Garland, 71 U.S. 333 (1867). In practical terms, the Act could not expose anyone to prosecution contrary to the will of the President.

42. 448 U.S. 607 (1980).

43. Id. at 685-86 (Rehnquist, J., concurring) (citations omitted).

44. See id. 
accountability. ${ }^{45}$ Modern public choice theory suggests that delegation enables individual legislators to reduce the political costs of policies that injure relatively uninterested voters, witlout losing credit for benefits bestowed on those interest groups intensely enougli motivated to trace the cliain of power. 46

This public clioice analysis has considerable force, but falls short of inaking a constitutional case for the intelligible principle requirenent. The approacli suggests that delegation would satisfy article I if Congress inade the delegate coinpletely accountable for all of its actions. No one could then doubt the ultinately congressional source of legal rules. But even if Congress could soineliow arrange perfect after-tlie-fact accountability, the result would offend article I. Chadha, after all, involved precisely a device that rendered the delegate of legislative power too accountable to the legislative brancli. Perfect accountability would not stop Congress froin avoiding constitutional cliecks on its lawmaking powers by apparently delegating authority to, but in fact exercising power through, congressional creatures.

Any intelligible principle requirement, then, inust ensure that the delegate implement Congress's policy clioices according to article I constraints. It is entirely conceivable that the delegate might be less susceptible thian Congress to the perverse incentives of interest group politics. ${ }^{47}$ As a constitutional matter, however, the point is less that delegation predictably leads to results condemned by contemporary policy analyses than that delegation leads to decisions different froin those that Congress would have made if pressed to do so. Delegating power for the purpose of avoiding the institutional incentives operating on Congress is precisely what the nondelegation doctrine forbids.

The public choice justification for the nondelegation doctrine is therefore no inore satisfactory than the defense of expansive delegation on the ground that interest group politics render congressional decisionmaking perverse. Both arguments amount to rewriting the Constitution, one version inoving to strip Congress of certain article I powers, the other moving to prolibit Congress from delegating any such power be-

45. See J. ELy, supra note 27, at 131-34; T. Lowi, The END of Liberalism ch. 5 (2d ed. 1979); Aranson, Gellhorn \& Robinson, supra note 20, at 63-67; Schwartz, supra note 16, at 459-60; see also Schoenbrod, The Delegation Doctrine: Could the Court Give It Substance?, 83 Mich. L. REv. 1223, 1243-1246 (1985) ("The Court's current application of the delegation doctrine, by way of an amorphous and ultimately meaningless definition of legislative power, undercuts the accountability the Constitution seeks to protect.").

46. See Aranson, Gellhorn \& Robinson, supra note 20, at 64 .

47. See Mashaw, ProDelegation: Why Administrators Should Make Political Decisions, 1 J.L. ECON, \& ORG. 81, 85 (1985). 
cause congressional outcomes are likely to be less perverse than agency outcomes.

This is not to say that notions of institutional competence and political incentives are irrelevant. Rather, I submit that the analytical starting point is the explicit delegation of article I powers to Congress. The reasons for reposing powers in a body of that cliaracter control the extent of furtlier delegations. ${ }^{48}$ We must work backward from the authoritative text to discover the governing principles, not forward from our favored principles to discover the autlioritative text. As I have argued above, ${ }^{49}$ the principle underlying the article I process is a preference for either private ordering or state legislation over federal legislation, a principle implemented by empowering a variety of constituencies independently to block, but not to enable, federal legislation.

The intelligible principle requirement therefore has the object of ensuring that Congress inakes important policy decisions according to the pluralist constraints that the Constitution imposes on congressional action. The caselaw regularly recites, on behalf of this purpose, the requirement of an intelligible principle for vahid delegations of legislative power. ${ }^{50}$ Violation of this requirement alone is sufficient to invalidate an otherwise constitutional delegation: at least one Supreme Court case, never overruled, has held a delegation unconstitutional without stating any plausible grounds other than the lack of an intelligible principle.

In Panama Refining Co. v. Ryan, ${ }^{51}$ the Court struck down section 9(c) of the same National Industrial Recovery Act that it later dispatched wholesale in Schecter Poultry. This section authorized the Presi-

48. See Freedman, Delegation of Power and Institutional Competence, 43 U. CHI. L. REV. 307, 336 (1976):

Whenever a court concludes that the Framers regarded the proper exercise of a specific legislative power as closely dependent upon the unique institutional competence of Congress, the non-delegation doctrine would prohibit Congress from delegating that power to another. In these circumstances, the act of delegation would so aiter the manner of the power's exercise that the resulting arrangement would no longer be compatible with the Framers' reasons for vesting the power in an institution whose character and nature are defined in the special ways-of political responsiveness and broad-based diversity-that those of Congress are.

Professor Freedman argues that the nondelegation doctrine primarily forbids any exercise of core legislative functions, such as taxing and impeachment. The limitation of his analysis to a few legislative powers, however, is unconvincing, because the reason for vesting any of the article $\dot{I}$ powers in Congress is to confine the exercise of that power according to the obstacle-course procedures of article $I$, section 7 , and the institutional incentives bearing on an elected assembly. Of course, certain constitutional provisions may be inconsistent with any delegation, however clearly directed. It may also be that certain article I powers may be delegated with less specificity than others.

49. See supra note 27 and accompanying text.

50. See, e.g., Industrial Union Dep't v. American Petroleum Inst., 448 U.S. 607, 646 (1980) (citing Schecter Poultry and Panama Refining) (plurality opinion); Amalgamated Meat Cutters v. Connally, 337 F. Supp. 737, $746-51$ (D.D.C. 1971).

51. 293 U.S. 388 (1935). 
dent to prohibit interstate shipment of petroleuin produced or withdrawn froin storage in violation of state laws designed to cope with an oil glut..$^{52}$ If Congress really failed to provide an intelligible principle to guide the President in deciding when to prohibit such shipments, ${ }^{53}$ section 9(c) was void because it authorized the President to pass legislation free from the checks imposed by bicamerahism and the broad range of interests represented in Congress. ${ }^{54}$

The irreducible element of controversy in delegation cases is the presence or absence of an intelligible principle. My thesis, however, does not depend on how broadly or narrowly the courts interpret the intelligible principle requirement, although the scope of procedural protection accorded by the requireinent may vary somewhat on that basis. All that the connection between the nondelegation doctrine and the procedural due process cases depends on is the existence of a constitutional requireinent that Congress define federal policy. A surprising consensus-one that covers the ideological spectrum from J. Skelly Wright to William $\mathrm{H}$. Rehnquist-recognizes such a requirement, however unclear and contested its ultimate dimensions may be. ${ }^{55}$

\section{The Right/Privilege Distinction and the NONDELEGATION DOCTRINE}

\section{A. The Right/Privilege Distinction and Its Defenders.}

The paradigmatic example of the right/privilege distinction comes froin McAuliffe v. Mayor of New Bedford, 56 in which a policeman was fired for violating a regulation that impinged upon his right of free expression. Justice Holmes noted tliat "tlie petitioner may liave a constitutional right to talk politics, but lie lias no constitutional riglit to be a policeman."57 The state conditioned the unprotected privilege of being a policeman on giving up, at least in part, the protected right of free expression. ${ }^{58}$

52. Id. at 406 .

53. Cf. id. at 434-35 (Cardozo, J., dissenting).

54. See id. at 430.

55. Those who have called for more vigorous enforcement of the intelligible principle requirement include Chief Justice Rehnquist, Judge Wright, Judge McGowan, Dean Ely, and Professors Lowi, Schwartz, Freedman, Aranson, Gellhorn, and Robinson. See American Petroleum Institute, 448 U.S. at 687 n.6 (Rehnquist, J., concurring); J. ELY, supra note 27, at 131-34; T. LowI, supra notc 45, ch. 5; Aranson, Gellhorn \& Robinson, supra note 20, at 43-45; McGowan, Congress, Court, and Control of Delegated Power, 77 CoLUM. L. REv. 1119, 1127-30 (1977); Wright, supra note 27, at 585 .

56. 155 Mass. 216, 29 N.E. 517 (1892).

57. Id. at 220,29 N.E. at 517 .

58. Id., 29 N.E. at $517-18$. 
In defining constitutionally protected rights, the fifth and fourteenth amendments forbid governmental deprivations of "life, liberty or property" without "due process of law." In the absence of a constitutional right to government benefits, a constitutional distinction between rights and privileges would authorize the government to condition benefits on acceptance of whatever procedures the legislature provides for distributing or terminating the benefits in question. In 1970, however, in Goldberg v. Kelly, the Supreme Court held that current welfare recipients (but not applicants) have a constitutional property interest in their benefits. ${ }^{59}$ Accordingly, the Court found itself required to determine what "process" was "due," tliat is, what procedures the Constitution required the state to follow before terminating benefits. ${ }^{60}$

Goldberg clearly rejected the claim that the government's constitutional authority to eliminate an entitlement implies the authority to condition the entitlement on procedures of its own choosing. But the reasoning that justified this rejection of the riglit/privilege distinction is less than coinpelling. Goldberg did no more than refer to prior cases in which the Court had found that constitutional entitlements had the practical effect of violating constitutional rights to mobility, free exercise of religion, and the privilege against self-incrimination. ${ }^{61}$

Tlie fear that allowing conditional entitlements might lead legislatures to coinpel the wholesale waiver of constitutional rights has persuaded Supreme Court majorities for at least seventy years. ${ }^{62}$ This

59. 397 U.S. 254 (1970). The Court's approach at least partially approved Professor Reich's "new property" argument for recognizing enforceable "entitlements" to prevent the government from suppressing individual hberties by manipulating its largess. See Reich, Individual Rights and Social Welfare: The Emerging Legal Issues, 74 YALE L.J. 1245, 1256 (1965); Reich, The New Property, 73 YALE L.J. 733, 771-86 (1964).

60. 397 U.S. at $260-66$.

61. 397 U.S. at 262-63.

62. For example, in Western Union Tel. Co. v. Kansas, 216 U.S. 1 (1910), the Court invalidated a state statute that conditioned a corporation's privilege of conducting intrastate business on the payment of a fee figured as a percentage of total authorized capital (including capital dedicated to business in other states and to interstate cominerce). A parade of horribles figured in the decision, although the nature of the horrible may have changed somewhat between then and now:

Can such a regulation be deemed constitutional any more than one requiring the company, as a condition of its doing intrastate business, that it should surrender its right, for instance, to invoke the protection of the Constitution when it is proposed to deprive it of its property without due process of law, or to deny it the equal protection of the laws?

Id. at 35 . By 1926 the parade of horribles was evident in its modern form, although it was still deployed in the context of state restrictions on the privilege of doing busmess:

It would be a palpable incongruity to strike down an act of state legislation which, by words of express divestment, seeks to strip the citizen of rights guaranteed by the Federal Constitution, but to uphold an act by which the same result is accomplished under the guise of a surrender of a right in exchange for a valuable privilege which the state threatens otherwise to withhold. It is not necessary to challenge the proposition that, as a general rule, the state, having power to deny a privilege altogether, may grant it upon such conditions as it sees fit to impose. But the power of the state in that respect is not unlimited; and 
parade-of-horribles approach, however, seems defective for three related reasons. First, the independent constitutional rights that legislative conditions might undermine offer a direct reason for prohibiting the conditional dispensation of entitlements. First amendment analysis, for example, condemns conditioning entitlements on the waiver of the right to free expression or religious exercise. ${ }^{63}$ As Professor Westen points out, courts can best resolve these cases by inquiring specifically into the degree of practical restraint that particular conditions impose on particular constitutional rights. ${ }^{64}$ This approach curtails the parade of horribles, without assuming free-wheeling judicial authority to second-guess legislative entitlement decisions.

one of the limitations is that it may not impose conditions which require the refinquishment of constitutional rights. If the state may compel the surrender of one constitutional right as a condition of its favor, it may, in like manner, compel a surrender of all. It is inconceivable that guaranties embedded in the Constitution of the United States may thus be manipulated out of existence.

Frost v. Railroad Conim'n, 271 U.S. 583, 593-94 (1926). Holmes, joined by Brandeis, urged in dissent that the greater power of abolishing the privilege includes the lesser of conditioning it. Id. at 600-02 (Holmes, J., dissenting).

At the very dawn of due process adjudication under both the fifth and fourteenth amendments, the Court expressly rejected the idea that due process of law was whatever law the legislature had provided. See Murray's Lessee v. Hoboken Land \& Improvement Co., 59 U.S. (18 How.) 272, 276 (1855) (rejecting possibility that Congress could inake "any process 'due process of law', by its inere will"). The Court gave a similar answer about the fourteenth amendment in Davidson v. New Orleans, 96 U.S. 97, 102 (1877):

It is easy to see that when the great barons of England wrung from King John, at the point of the sword, the concession that neither their lives nor their property should be disposed of by the crown, except as provided by the law of the land, they ineant by "law of the land" the ancient and custoniary laws of the English people, or laws enacted by the Parliament of which those barons were a controlling element. It was not in their minds, therefore, to protect themselves against the enactment of laws by the Parliament of England. But when, in the year of grace 1866, there is placed in the Constitution of the United States a declaration that "no State shall deprive any person of life, liberty, or property without due process of law," can a State make any thing due process of law which, by its own legisiation, it chooses to declare such? To affirm this is to hold that the prohibition to the States is of no avail, or has no application where the invasion of private rights is effected under the forms of State legislation. It seens to us that a statute which declares in terms, and without more, that the full and exclusive title of a described piece of land, which is now in A., shall be and is hereby vested in B., would, if effectual, deprive A. of his property without due process of law, within the meaning of the constitutional provision.

The Court, however, was and is reluctant to constitutionalize the law of property. If the fourteenth amendment does not contain a substantive definition of property, the positivist approach is logically unassailable. Even if the amendment does contain an independent definition of property, that definition would defer to state positive law to such an extent that with respect to entitlenent programs, the states could define eligibility in purely procedural terms. See infra notes 98-100 and accompanying text.

63. See, e.g., Sherbert v. Verner, 374 U.S. 398 (1963) (South Carolina could not deny unemployment benefits to Seventh-Day Adventist who would not work on weekends because of religious beliefs); Speiser v. Randall, 357 U.S. 513 (1958) (Cahfornia could not condition certain tax exeinptions on requirement that taxpayer sign statement indicating that he does not advocate overthrow of United States government).

64. Westen, Incredible Dilemmas: Conditioning One Constitutional Right on the Forfeiture of Another, 66 IowA L. REv. 741 (1981). 
Second, the judicial justification for rejection of the right/privilege distinction is illogical. Unless the Court is willing to recognize a substantive constitutional right to government transfer payments or public employment ${ }^{65}$-something it has never been willing to do-the unconstitutional conditions doctrine does not apply to entitlement cases. When the federal government conditions entitlements on waiver of rights to free expression or against self-incrimination, the demal of a government benefit punishes an independent constitutional right. In contrast, when transfer payments or public employment are conditioned on such a waiver, the constitutional right is to "property," which the Court equates with statutory entitlement. Yet the statute creating the entitlement defines "property" in terms of the results of statutory procedures. If the only "property" the claimant has is what the statute creates, why is the procedural aspect of the entitlement open to judicial manipulation when the substantive component is not?

The accepted rationale appears to involve nothing more than the claim that regrettable consequences would follow from the obvious interpretation of the Constitution. Pohicy arguments have a role in constitutional interpretation, but the policies on which constitutional adjudication turns ought to have some basis in the document itself. The judicial rejection of the right/privilege distinction, however, admits that a plausible reading of the document is denied because judges prefer that the reading were not plausible.

The Court's latest rejection of the right/privilege distinction makes clear the poverty of modern procedural due process doctrine. In Cleveland Board of Education v. Loudermill, 66 the Court unequivocally rejected the right/privilege distinction without offering any justification beyond the parade of horribles:

The point is straightforward: the Due Process Clause provides that certain substantive rights--life, liberty, and property-cannot be deprived except pursuant to constitutionally adequate procedures. The categories of substance and procedure are distinct. Were the rule otherwise, the Clause would be reduced to a inere tautology. "Property" cannot be defined by the procedures provided for its deprivation any more than can life or liberty. The right to due process "is conferred, not by legislative grace, but by constitutional guarantee. While the legislature may elect not to confer a property interest in [public] employment, it may not constitutionally authorize the deprivation of such an interest, once conferred, without appropriate procedural

65. E.g., Goldberg v. Kelly, 397 U.S. 254, 262 (1970) (government transfer payments); Board of Regents v. Roth, 408 U.S. 564, 576 (1972) (public employment).

66. 470 U.S. 531 (1985). 
safeguards."67

The quotation is negatively impressive; I have omitted no further attempts at justification. After generations of litigation, all the Court is willing to say is that the right/privilege distinction is not the law. "Mere fiat" is a phrase too often used, but surely those words describe the Loudermill Court's approach.

Third, a substantial policy argument opposes the rejection of the right/privilege distinction. As Justice Black, dissenting in Goldberg, ${ }^{68}$ and Judge Easterbrook ${ }^{69}$ have observed, the imposition of judicial procedures may reduce the liberality of legislative entitlements. Cost and delay in removing individuals from welfare rolls or public employment may reduce the government's willingness to grant those entitlements in the first place. ${ }^{70}$ The individual's stake in the protected right is one term in the Mathews balancing formula, which determines the scope of procedural protection. The Mathews approach thus recognizes the seriousness of the problem.71 But it also admits, albeit tacitly, that whether judges possess the technical and constitutional competence to make this determination remains dubious. ${ }^{72}$

Cominentators defending the Court's approach have sought to find within it a dignitary theory of due process. ${ }^{73}$ Beginning with Professor Van Alstyne's 1968 article, ${ }^{74}$ they claim that the due process clause recognizes a liberty interest in fair procedures. ${ }^{75}$ The point of these digni-

67. Id. at 541 (quoting Arnett v. Kennedy, 416 U.S. 134, 167 (1974) (Powell, J., concurring in part and concurring in the result in part)).

68. 397 U.S. at $278-79$ (Black, J., dissenting).

69. Easterbrook, Substance and Due Process, 1982 SUP. CT. REv. 85, 111-15.

70. Verkuil, The Search for a Legal Ethic: The Adversary System, Liberalism and Beyond, 60 SOUNDINGS 54, 62 n.34 (1977):

Before Goldberg, enrollment in AFDC programs was largely based upon self-certification of eligibility through the use of sworn statements which could be reviewed later and ineligibles culled from the rolls through expeditious termination procedures. Since Goldberg made the termination decision much more protracted, many states tightened up on the initial enrollment process. This change necessarily delays entry into the program for eligible claimants as well as delaying departure of ineligibles.

71. See Mathews v. Eldridge, 424 U.S. 319, 334-35 (1976); supra notes 6, 11 and accompanying text.

72. Cf. Easterbrook, supra note 69, at 118 ("The contents of the legislation are the best available evidence about the value the affected people place on hearings.").

73. See Mashaw, Administrative Due Process: The Quest for a Dignitary Theory, 61 B.U.L. Rev. 885 (1981); Michelman, Formal and Associational Aims in Procedural Due Process, in Nomos XVIII: Due Process 126 (J. Chapman \& J. Pennock eds. 1977).

74. Van Alstyne, The Demise of the Right-Privilege Distinction in Constitutional Law, 81 HARv. L. REv. 1439 (1968).

75. Prior to Goldberg, Roth, and Mathews, this made reasonably good sense. There are hints of this approach in Cafeteria \& Restaurant Workers Union v. McElroy, 367 U.S. 886 (1961), a watershed case in which some of the Justices linked administrative due process to the natural-law concept of "fundamental fairness" that governs due process in criminal cases. Id. at 902 (Brennan, J., dissenting). But the criminal cases by definition involve the potential deprivation of liberty or property. 
tary theories is that constitutional "liberty" includes freedoin from unfair procedures. If this is so, then judicially created property interests-like the interests created in welfare benefits by the Goldberg Court ${ }^{76}$-are irrelevant, for the freedoin froin unfair procedures is independent of context: the government inay not injure anyone without fair procedures, irrespective of whether the injury affects liberty, property, privilege, or preference. The dignitary theories conflict with the Court's preoccupation with identifying protected categories of entitleinent. More importantly, they conflict with the textual language inspiring this preoccupation. Since all dignitary theories depend on equating liberty and process, ${ }^{77}$ all read the due process clause to forbid the deprivation of liberty without liberty, or the deprivation of process without process.

Admittedly, a powerful argument urges interpretation of the due process clause as a unitary term of art, rather than as a concatenation of words whose contemporary meaning turns out to be agreeable. As John Ely notes, "[u]ntil recently, the general outlines of the law of procedural due process were pretty clear and uncontroversial. The phrase 'life, liberty or property' was read as a umit and given an open-ended, functional interpretation, which meant that the government couldn't seriously hurt you without due process of law."78 But even treating the due process clause as requiring the (substantive) rule of law informed by an irreducible minimum of extrimsic justice, the nondelegation predicate makes sense. In a liberal democracy the rule of law means living according to the prescriptions of an elected assembly, defined by constitutional rules of validity. Surely, in sucli a democracy, adherence by governinent functionaries to the enactments of the popular assembly lies close to the heart of the "law of the land."79 The nondelegation doctrine thus depends not just on article I, but on a further commitment to abide by and enforce the constitutional rules of vahidity there ordained. If due process is taken to mean even as little as fidelity to valid positive law, hearing rights could be imposed as a means of enforcing these article I rules of validity. The doctrinal connection I propose, then, is consistent with both reductionist

76. See supra note 59 and accompanying text.

77. See, e.g., Mashaw, supra note 73, at 887.

78. J. ELY, supra note 27, at 19 (footnote omitted).

79. The language of the due process clause traces to chapter 39 of Magna Carta. See, e.g., A. HowARD, THE ROAD FROM RUNNYMEDE 298-315 (1968). In chapter 39, the King pledged that "[n]o freeman shall be arrested, or detained in prison, or deprived of his freehold, or outlawed, or banished, or in any way molested; and we will not set forth against him, nor send against him, unless by the lawful judgment of his peers and by the law of the land." R. POUND, THE DEVELOPMENT OF Constitutional GUARANTEES OF LIBERTY 123 (1957). Ironically, although the due process clause protects many more people (persons rather than freemen), Magna Carta protects a broader range of individual interests than does the Court's insistence on finding "liberty" or "property" before imposing any procedural protection. 
and expansionist readings of the due process clause as a term of art, and with the Supreme Court's contemporary plain man's literalism.

The basis of my thesis should now be apparent, and takes the form of three propositions. First, the intelligible principle requirement states a recognized, but effectively inchoate, rule of constitutional law. Second, the procedural due process cases reflect a perceived need to confine the exercise of administrative power according to rational procedures. Third, the procedural due process doctrine lacks a legitimate predicate in recognized rules of constitutional law. The conclusion that follows is that the nondelegation doctrine-not the stated rationale of the due process cases-actually confines legislative power.

\section{B. Enforcing the Liberty Interest in Legislative Legitimacy.}

In Panama Refining, the Court allowed the Panaina Refining Coinpany standing to contest a legislative delegation that caused it injury. ${ }^{80}$ The Court recognized Chadha's standing to sue on the saine basis. ${ }^{81}$ I subinit that both litigants asserted a constitutional liberty interest, and that just as the Court has legitinately granted relief in particular cases of unconstitutional delegation, the Court can legitimately inpose procedural safeguards to enforce the nondelegation doctrine's intelligible principle requireinent.

If a statutory delegation survives scrutiny because it states an intelligible principle, then conforinity to that principle is a constitutional as well as a statutory issue. Departure froin the principle ineans that the statutory delegation exceeds constitutional limitations and that the body receiving the delegation supersedes Congress as the policymaker.

If individuals suffering injury from violations of the nondelegation doctrine inay sue for direct redress, as Panama Refining and Chadha suggest, then the Court inay also prescribe, and allow individuals to sue to enforce, prophylactic procedures that prevent the violation of the nondelegation doctrine. In other areas, the Court has found that enforcement of constitutional requirements depends on such procedures. For exainple, in Miranda v. Arizona, the Court required the adıninistration of warnings about criminal defendants' rights to silence and to counsel in order to enforce the fifth ainendment right against selfincrimination. ${ }^{82}$ In Addington v. Texas, the Court required proof by clear and convincing evidence before an individual inay be deprived of liberty in a civil coinınitinent proceeding. ${ }^{83}$ Both Miranda warnings and

\footnotetext{
80. Panama Ref. Co. v. Ryan, 293 U.S. 388, 414-15 (1935).

81. INS v. Chadha, 462 U.S. $919,935-36$ (1983).

82. 384 U.S. 436, 492-95 (1966).

83. 441 U.S. $418,431-33$ (1979).
} 
Addington burdens of proof are judicially created and judicially enforceable procedural requirements that protect constitutional rights even when the complaining party cannot establish that the government has violated those rights.

More direct support for the existence of a right to fair procedures comes in recent Supreme Court cases requiring clear congressional authorization of admimistrative action before a statute can be interpreted as delegating power im possible conflict with the nondelegation doctrine. ${ }^{84}$ If the Court exphicitly rehies on this intelligible principle requirement to narrow facially sweeping delegations, why may it not also impose hearing requirements toward the same object? Either approach constrains illegitimate exercises of delegated power that might otherwise escape redress. But a retrospective judicial narrowing of overbroad delegations merely transfers the illegitimate exercise of article I powers to the courts-statutory "construction" with a vengeance-while a prospective requirement of fair procedures reduces the chance that the delegate will disregard, or fail to discover, what guidance Congress has provided. ${ }^{85}$

Will hearing requirements actually enforce the intelligible principle requirement? The due process cases proceed on this very assumption. The traditional due process analysis in Mathews v. Eldridge views hearings strictly as a means to the end of accurate resolution according to legislative criteria. ${ }^{86}$ Even in the rulemaking context, a hearing (paper or otherwise) increases the likelihood that the rule selected by the congressional delegate conforms to the imtelligible principle governing the delegation.

From a public choice perspective, procedural guarantees such as private hearing rights tend to merge agency and congressional procedures.

84. See Industrial Union Dep't v. American Petroleum Inst., 448 U.S. 607, 645 (1980) (plurality opinion) ("In the absence of a clear nrandate in the Act, it is unreasonable to assume that Congress intended to give the Secretary ... unprecedented power . . . ."); National Cable Television Ass'n v. United States, 415 U.S. 336, 340-42 (1974) (ambiguous statute found not to delegate taxing power to the FCC); Greene v. McElroy, 360 U.S. 474, 502-03 (1959) (various defense authorization statutes did not delegate to the Department of Defense the power "to fashion progranis under which persons nuay be seriously restrained in their eniployment opportunities"); Kent v. Dulles, 357 U.S. 116,129 (1958) (Court "will construe narrowly all delegated powers that curtail or dilute" fundamental liberties, such as the right to travel).

85. The Court's practice of narrowly construing statutes that delegate power to administrators without an intelligible principle raises the question whether, under Erie R.R. v. Tompkins, 304 U.S. 64 (1938), Congress nuay attenipt to assign article III courts the power to fashion federal common law under circumstances that would require invalidating an otherwise identical grant of power to an administrative agency. While delegations to the "least dangerous branch," in comparison with delegations to the President, are less likely to threaten the structural integrity principle, the nere fact that the congressional delegate is a judge presents no reason for abandoning the intelligible principle requirement.

86. See Mathews v. Eldridge, 424 U.S. 319, 343-49 (1976). 
Hearing rights inhibit an agency's abihity to evade responsibility and force the agency to acknowledge those interests that might have opposed congressional legislation. ${ }^{87}$ Commentators from a variety of perspectives have identified these and other functions of due process and the nondelegation doctrine. ${ }^{88}$ The time has coine to acknowledge the relationship between the two doctrines, in the interests of enforcing the nondelegation doctrine and of grounding the due process cases on a substantial constitutional warrant.

\section{IMPLICATIONS}

\section{A. The "Protected Interest" Analysis.}

Recognition of freedom from the illegitimate exercise of legislative power as a protected liberty interest would extend due process scrutiny to any exercise of official power over individuals by a congressional delegate. This would render academic some of the more arbitrary distinctions in the Court's "protected interest" cases. The tenured and untenured employee alike would enjoy procedural protection against termination, except according to properly enacted legislative criteria. ${ }^{89}$ The eerie contrast between transfer payinent decisions concerning imitial ehgibility and those regarding termination would becoine less stark. ${ }^{90}$ Under the approach I suggest, the Court would retain some flexibility in reviewing the procedures appropriate at different stages of the admimistrative process, but would no longer need to allow the governinent limitless discretion over vital entitleinent decisions.

My approach would not lead to any great increase in litigation. The Court has already invited anyone suffering grievous loss to sue on due process grounds, since the criteria defining protected interests are vague

87. See also supra note 46 and accompanying text (discussing how delegation enables Congress to avoid accountability).

88. See S. BARBER, supra note 18, at 30-34; Davis, A New Approach to Delegation, 36 U. CHI. L. REv. 713, 730-33 (1969); Schoenbrod, supra note 45, at 1283-89; Stewart \& Sunstein, Public Programs and Private Rights, 95 HARv. L. Rev. 1193, 1261-63 (1982). Professors Stewart and Sunstein come close to endorsing the approach defended here, but they do not interpret the nondelegation doctrine as forbidding legislative definition of entitlements in procedural terms. Accordingly, they apparently would require some other basis for imposing hearing rights when the legislature manifests its intention to create entitlements in procedural terms.

Illuminatingly, Judge Easterbrook appears to agree that the nondelegation doctrine could support individual hearing rights. He rejects the possibility because he believes that " $[t]$ he nondelegation doctrine is a name without a doctrine." Easterbrook, supra note 69, at 118-19.

89. Cf. Board of Regents v. Roth, 408 U.S. 564,569 n.5 (1972) (no cause required for university's failure to rehire nontenured employee, but cause required to fire tenured employee).

90. Cf. Goldberg v. Kelly, 397 U.S. 254, 263-64 (1970) (termination of welfare payments without administrative hearing violates due process clause, but denial of same benefits to new applicants without same hearing does not). 
enough to give any such person hope, if not confidence, of success. ${ }^{91} \mathrm{Ju}-$ dicial restraint in imposing extrastatutory procedures could discourage litigation at least as well as the vague protected interest requirement and would avoid the ugly implication that some governmental decisions can cause great hardship without any review for procedural fairness.

Recognizing a liberty interest based on the nondelegation doctrine would not eliminate other protected interests, but it might enable the Court to work out a more principled and coherent approach to their definition. For one thing, it would mean the end of the "new property" approach. ${ }^{92}$ But for the nondelegation doctrine, Congress could create entitlenients in procedural terms; therefore, aside from the hiberty niterest that the nondelegation doctrine defines, no constitutional property interest could arise from legislation containing procedures for defeasance of the entitlenients it creates.

Traditional jurisprudence recognizes certain liberty interests that state governments can terminate ouly when they follow certain procedures. For example, a state can impose criminal punishınent only after conducting a fair trial for violation of already existing law. ${ }^{93}$ If, as the Suprenie Court lias held, the due process clause imposes on the states the responsibility of justly compensating those fron whom they take private property for public use, ${ }^{94}$ it would seem that the fourteentli amendinent includes a constitutional definition of property. If property niterests arose only fronı state property law, it would be nonsense to talk of state takings. ${ }^{95}$ Nonetlieless, any constitutional definition of property, as the takings example suggests, would necessarily defer to the myriad variations in state property law, and would be limited to interests the Court was willing to require states to recognize as a substantive nuatter. Any such definition would exclude state entitlenient programs like the one at issue in Goldberg. The logical force of the right/privilege distinction excludes the Goldberg lolding as judicial usurpation of a legislative func-

91. In particular, under Perry v. Sinderman, 408 U.S. 593 (1972), informal assurances of tenure may establish the existence of a property interest. The disgruntled probationary employee thus has at least an open route to the jury, notwithstanding the threshold requirement of a protected interest.

92. See supra notes 59.60 and accompanying text.

93. See United States v. Salerno, 107 S. Ct. 2095, 2102 (1987) (upholding preventive detention statute, but conceding “ 'general rule' of substantive due process that the governinent may not detain a person prior to a judgment of guilt in a criminal trial"); Thompson v. City of Louisville, 362 U.S. 199 (1960) (guilty verdict supported by no evidence violates due process); Moore v. Dempsey, 261 U.S. 86 (1923) (mob-dominated trial violates due process); Johnson v. United States, 805 F.2d 1284, 1288 (7th Cir. 1986) (Posner, J.) ("To punish a person criminally for an act that is not a crime would seem the quintessence of denying due process of law.").

94. Chicago, B. \& Q.R.R. v. City of Chicago, 166 U.S. 226 (1897).

95. The point was not lost on the Chicago, Burlington \& Quincy Railroad Court, which explicitly relied on a substantive, natural-law interpretation of "property." See id. at 231-41. 
tion. Accordingly, in the absence of a federal constitutional right to have state legislative entitlements defined substantively rather than procedurally, ${ }^{96}$ federal judicial scrutmy of state entitlement programs should all but be eliminated.

\section{B. The "Process Due" Analysis.}

If my thesis is correct, every exercise of delegated article I powers that inflicts injury would be subject to scrutimy under the fifth amendment due process clause. Predicatimg this scrutiny on the nondelegation doctrine would necessitate refinement of the balancing test that governs the analysis of what process is due a protected interest. Under Mathews v. Eldridge, the Court weighs the individual interest in avoiding erroneous deprivation, the government's interest in avoiding the cost of the procedure in question, and the contribution the procedure might make to improving the quality of decisions. ${ }^{97}$

Under the nondelegation approach, the courts will still face judgments about the usefulness of possible procedural safeguards. Whether a procedure protects property interests defined by current law, or freedoin from unfair procedures under article I, as I propose, courts can only require the procedure as a means to the end of enforcing the underlying constitutional right. ${ }^{98}$

96. The most likely source for such a federal constitutional right is the guarantee clause, U.S. CoNsT. art. IV, $\S 4$, cl. 1. See J. ELY, supra note 27, at 240-41 n.78 (arguing that guarantee clause imposes nondelegation doctrine on the states); Comment, The Guarantee of Republican Government: Proposals for Judicial Review, 54 U. CHI. L. REv. 208, 232-35 (1987) (same). The guarantee clause, however, remains unenforceable under the political question doctrine. See Baker v. Carr, 369 U.S. 186, 209-37 (1962). The apportionment decisions, purportedly based on the equal protection clause, see id. at 226; Reynolds v. Sims, 377 U.S. 533 (1964), may imply a different conclusion. See Merritt, The Guarantee Clause and State Autonomy: Federalism for a Third Century, 88 Colum. L. REv. 1, 70-72 (1988) (dicta in apportionment cases suggest justiciability of some guarantee clause cases). These decisions arguably indicate that the guarantee clause is alive and well but living under an assumed name. See Baker, 369 U.S. at 297 (Frankfurter, J., dissenting) ("The present case involves all of the elements that have made the Guarantee Clause cases non-justiciable. It is, in effect a Guarantee Clause claim masquerading under a different label."). Perhaps Goldberg and its progeny reflect the same masquerade. The Court should either unveil the living guarantee clause, or get out of the business of policing the enforcement of state statutes.

97. See Mathews v. Eldridge, 424 U.S. 319, 332-35 (1976); supra note 6, 11 and accompanying text.

98. This would do no more than deny openly what current law denies implicitly-a constitutional right to procedure for its own salke. If a factual dispute about the applicability of a valid rule is a precondition for a hearing, see infra note 105 , then the Constitution commands process only when process has some chance of preventing the misapplication of some other legal norm. With respect to federal tribunals, the delegation approach would authorize judicial scrutiny of procedures leading to individual injury, without the fiction of making up a new constitutional value. See Easterbrook, supra note 69 , at 115-18 (justly disparaging diguitary theories). 
The nature of the underlying right will still affect the analysis by determining the clarity of congressional policy required under the nondelegation doctrine. A relatively vague delegation may withstand scrutiny if the power delegated governs commercial activity. ${ }^{99}$ This is not to disparage property rights but only to admit their secondary inportance to rights to hife and liberty. The hierarchy of judicial value, with the exercise of political freedoms and the inaintenance of life itself at the apex, will appear in delegation cases just as it lias in due process cases.

The difference under iny proposal would be tliat courts would measure the sufficiency of legislative procedures against the goal of nondelegation, rather than against the goal of protecting some otlier interest. Thus, in a ruleinaking proceeding pursuant to a statutory delegation presenting a close case on the intelligible principle requirement, extensive procedures miglit be required to find the elusive congressional mandate. In an adjudicatory proceeding brought under sucl a statute (in the absence of clarifying regulations), similar considerations would apply.

In general, the Supreme Court lias dechined to scrutimize rulemaking procedures very rigorously, ${ }^{100}$ Two venerable but vital decisions,

99. See Schoenbrod, supra note 45, at 1285. Professor Schoenbrod criticizes the Court's practice of policing delegations implicating liberty more rigorously than it policies delegations implicating property. But no procedure can make absolutely certain that the congressional agent has acted as Congress would have acted in its place. The risk of error that is constitutionally tolerable is not the same in every case with constitutional rights at stake. See Monaghan, Constitutional Fact Review, 85 Colum. L. Rev. 229, 267-68 (1985). Thus, not all potential constitutional violations deserve equally effective preventive procedures. Indeed, not all violations even of the same constitutional provision are of equal concern. For example, an action under Bivens v. Six Unknown Named Agents of Fed. Bureau of Narcotics, 403 U.S. 388 (1971), to recover damages inflicted by a search executed in good-faith reliance on a warrant and an action for damages inflicted by unreasonably shooting dead a fleeing suspect are both grounded on the fourth amendinent. The two suits, however, have radically different chances of success. Compare Tennessee v. Gamer, 471 U.S. 1 (1985) (use of deadly force by police officer to seize a felon violates fourth amendment unless necessary to prevent escape and officer has probable cause to perceive danger) with Malley v. Briggs, 475 U.S. 335, 344-45 (1986) (police officer whose request for warrant caused unconstitutional arrest will be immune from liability unless the "warrant application is so lacking in indicia of probable cause as to render official belief in its existence unreasonable"). Just as the renedy required for violations of the fourth amendment turns in part on the degree to which particular state practices offend the values protected by the amendment, the procedures required to protect the liberty froin official injury unauthorized by Congress vary with the inportance of the policy choice that a litigant claims Congress failed to make. I agree with Professor Freedinan that the generality with which Congress may delegate declines as the constitutional competence of Congress with respect to the subject inatter increases. See Freedman, supra note 48, at 326-31. As noted supra at note 48, I disagree with the notion that Congress inight delegate some article I powers without anything in the way of an intelligible principle. Cf. Freedman, supra note 48, at 331-35. If these conclusions are correct, the courts might properly vary procedural safeguards depending on the consequences attending the mistaken exercise of delegated power.

100. See generally Minnesota State Bd. for Coinmunity Colleges v. Knight, 465 U.S. 271, 282-85 (1984) (individuals have no constitutional right to speak to public bodies making policy decisions). The Supreme Court also has rebuffed attempts by the United States Courts of Appeals to impose 
Londoner v. City \& County of Denver ${ }^{101}$ and Bi-Metallic Investment Board v. State Board of Equalization, ${ }^{102}$ illustrate the Court's approach. In Londoner, a local board assessed the property of the residents of a single street; the assessment was not reviewable by the state courts. The Supreme Court held that "where the legislature ..., instead of fixing the tax itself, commits to some subordinate body the duty of determining whether, in what amount, and upon whom it shall be levied, . . . due process of law requires that at some stage of the proceedings . . . the taxpayer shall have an opportunity to be heard." 103 In Bi-Metallic, a state agency ordered an across-the-board increase in the assessed valuation of all the property in Denver. Unlike the ruling in Londoner, this determination was reviewable in the state courts. Writing for the Court, Justice Holmes refused to recognize an individual right to be heard. When individuals suffer from general statutes, "[t] heir rights are protected in the only way that they can be in a complex society, by their poiver, immediate or remote, over those who make the rule."104

The Bi-Metallic Court's distinction, based on the impracticality of providing hearmg rights for a large number of individuals, is wide of the mark. Individual hearing rights in this context are not so much impractical as they are redundant; the case on behalf of each victim of a general deprivation is the same. A legislatively made rule involves no delegation; when a delegate makes the rule, however, due process requires that the proceeding be designed to conform the result to the legislative pohicy determination.

One procedural safegnard required in administrative proceedings might be the availability of judicial review, a more relevant distinction between Londoner and Bi-Metallic than the number of individuals affected by the rulings. ${ }^{105}$ Another safeguard would be prepublication of

procedures on agency rulemaking beyond those mandated by the Administrative Procedure Act. See Vermont Yankee Nuclear Power Corp. v. NRDC, 435 U.S. 519 (1978).

The Court's position notwithstanding, rulemaking proceedings can work the same deprivation as an adjudication. See, e.g., Burr v. New Rochelle Mun. Hous. Auth., 479 F.2d 1165, 1167-69 (2d Cir. 1973); Hahn v. Gottlieb, 430 F.2d 1243 (1st Cir. 1970). In both cases, a general ratemaking proceeding led to rent increases for subsidized housing beneficiaries. The courts concluded that due process did not require adversary procedures in the rulemaking context, but reached this conclusion under the "process due" inquiry, after the hitigants established a "protected interest." See also Note, Welfare, Due Process, and "Brutal Need": The Requirement of A Prior Hearing in State-Wide Benefit Reductions, 34 VAND. L. REV. 173, 195-208 (1981) (surveying decisions requiring hearings when legislative rules reduce welfare benefits).

101. 210 U.S. 373 (1908).

102. 239 U.S. 441 (1915).

103. Londoner, 210 U.S. at 385.

104. Bi-Metallic, 239 U.S. at 445.

105. Under the Administrative Procedure Act, agency action is not reviewable in court if statutes preclude review or if the matter is committed to agency discretion by law. 5 U.S.C. $§ 701$ (a) 
proposed rules to give a representative of the affected individuals' interests an opportunity to be heard. But once the agency has promulgated a valid rule, hearings are required only to the extent that individuals contest the applicability of the rule to their particular cases. ${ }^{106}$

The Administrative Procedure Act obviates most due process challenges to administrative rules at the federal level. Its notice-and-comment procedure ensures that interested persons have an opportumity to submit their views to delegates of congressional power. ${ }^{107}$ If an agency interprets its statutory mandate arbitrarily or capriciously, the courts have authority to set the interpretation aside. ${ }^{108}$ It is most unlikely that an agency could comply with the notice-and-comment procedures while denying an opportunity to be heard to representative members of the class adversely affected, and yet produce a decision that could survive review under the "hard look" doctrine. ${ }^{109}$

The most significant departure from current federal practice that the nondelegation approach iniglit bring about would be a restriction of agencies' ability to make policy in the adjudicatory context. Currently, these agencies can make policy either by promulgating rules or by adjudicating. ${ }^{110}$ If the nondelegation doctrine implied procedural riglits, the

(1982). If my thesis is correct, the nondelegation doctrine makes it unconstitutional for Congress to commit the exercise of legislative power entirely to agency discretion. Statutory preclusion of review might then render the delegation of legislative power unconstitutional, because no satisfactory method would limit the agency to its congressional mission. See Ethyl Corp. v. EPA, 541 F.2d 1, 68 (D.C. Cir.) (en banc) (Leventhal, J., concurring) ("Congress has been willing to delegate its legislative powers broadly $\rightarrow$ and courts have upheld such delegation-because there is court review to assure that the agency exercise the delegated power within statutory limits ....") (footnote omitted), cert. denied, 426 U.S. 941 (1976). But the nondelegation doctrine could support a constitutional right to review only when courts might make a meaningful contribution to enforcing the will of Congress. Thus, the exception for "matters committed to agency discretion" should be thought of not as applying when "there is no law to apply," but rather as applying when the congressional delegate is more likely than the federal courts to correctly identify the law enacted by Congress. Recent cases such as Heckler v. Chaney, 470 U.S. 821 (1985) (denying review of an administrative decision to forgo prosecution) and Webster v. Doe, $108 \mathrm{~S}$. Ct. 2047 (1988) (denying review of statutory, but not constitutional, challenges to personnel decisions of the Director of the Central Intelligence Agency) are rare exceptions in which review would make no contribution to ensuring compliance with congressional standards for the exercise of delegated power. The executive nature of the power at issue in Heckler might also explain that case.

106. See Codd v. Velger, 429 U.S. 624 (1977) (per curiam) (no due process hearing required when plaintiff fails to allege factual error by administrator); United States v. Storer Broadcasting Co., 351 U.S. 192, 205 (1956) (no right to adjudicatory hearing for party who admits violation of valid rule).

107. See 5 U.S.C. $\S 553$ (1982).

108. Id. $\$ 706(2)$ (a). For an example of substantive review of agency rulemaking, see Motor Vehicle Mfrs. Ass'n v. State Farm Mut. Ins. Co., 463 U.S. 29 (1983).

109. See, e.g., State Farm, 463 U.S. at 40-44.

110. See, e.g., NLRB v. Bell Aerospace Co., 416 U.S. 267, 294 (1974) ("[T]he Board is not precluded from announcing new principles in an adjudicative proceeding and ... the choice between rulemaking and adjudication lies in the first instance within the Board's discretion."). 
courts would then have a constitutional ground for requiring agencies to employ procedures calculated to produce the results intended by Congress. When operating under a general or vague statutory delegation, agencies would be able to make new policy only by rulemaking, not adjudication. ${ }^{111}$

By contrast, if the governing statute is clear, or an adjudication is governed by previously upheld rules clarifying the delegation, the need to protect liberty from the unauthorized exercise of legislative power would diminish. The need could never wholly vanish', though, for arbitrary factual findings could subvert any formal rule, however clear. ${ }^{112}$ The difference between nondelegation-based scrutiny and the Mathews approach would therefore be one only of degree, but this would nevertheless be a real difference.

\section{CONCLUSION}

I have proposed reliance on the nondelegation doctrine as a response to the logical problem posed by the right/privilege distmction and the Supreme Court's procedural due process cases. The delegation connection offers a principled basis for the Court's decisions, msofar as those decisions affirm a judicial obligation to confine the exercise of federal legislative power according to the constitutional rules of validity set out in article $I$. In contrast, the nondelegation doctrine fails to justify constitutional procedural requirements for state entitlement programs. ${ }^{113} \mathrm{Ab}$ sent a substantive constitutional right for such procedures to protect, the procedural due process cases involving state entitlenient progranis have no plausible justification.

111. See K. Davis, Discretionary Justice: A Preliminary InQuiry 52-96 (1969); H. Friendly, The Federal administrative Agencies: The NeEd for BetTer Definition of STANDARDS 25 (1962).

112. See Monaghan, supra note 99, at 272-73; see, e.g., ICC v. Louisville \& Nashville R.R. 227 U.S. 88, 91 (1913).

113. See Alexander, The Relationship Between Procedural Due Process and Substantive Constitutional Rights, 39 U. FLA. L. REV. 323, 340-41 (1987) ("Procedural due process applies to state and local governments, but no federal constitutional concern, except perhaps the non-justiciable Guaranty Clause, governs ultra vires state and local administrative action.") (footnote omitted). 